\title{
PENGARUH FED RATE, HARGA MINYAK DUNIA, BI RATE, INFLASI DAN KURS RUPIAH TERHADAP INDEKS SAHAM SYARIAH INDONESIA (ISSI) PERIODE TAHUN 2011-2017
}

\author{
Citra Puspa Mawarni ${ }^{1)}$, Anny Widiasmara ${ }^{2)}$ \\ Program Studi Akuntansi, Universitas PGRI Madiun \\ citrapm26@,gmail.com \\ anny.asmara@gmail.com
}

\begin{abstract}
The purpose of this study is to analyze the effect of FED Rate, World Oil Price, BI Rate, Inflation and Rupiah Rate to Indonesia Sharia Stock Index (ISSI) Period 2011-2017. The population of this study are Indonesian Sharia Stock Index, FED Rate, World Oil Price, BI Rate, Inflation and Rupiah Exchange Rate in 2011-2017. Determination of the sample using the census method by taking the entire population. This study uses secondary data, time series with the amount of data as much as 72 periods. Data analysis in this study used multiple linear regression analysis, $t$ test statistic, $F$ statistical test, and coefficient of determination test (R2) with the help of computer program SPSS version 17. The result of this analysis shows that the variable of the Rupiah Exchange Rate has a significant negative effect to the Indonesian Sharia Stock Index. However, the variable FED Rate, World Oil Price, BI Rate, and Inflation did not have a significant effect on Indonesian Sharia Stock Index.
\end{abstract}

Keyword : Indonesia Sharia Stock Index, FED Rate, World Oil Price, BI Rate, Inflation, Rupiah Exchange Rate

\begin{abstract}
ABSTRAK
Tujuan penelitian ini adalah untuk menganalisis pengaruh FED Rate, Harga Minyak Dunia, BI Rate, Inflasi dan Kurs Rupiah Terhadap Indeks Saham Syariah Indonesia (ISSI) Periode Tahun 2011-2017. Populasi penelitian ini adalah data Indeks Saham Syariah Indonesia, FED Rate, Harga Minyak Dunia, BI Rate, Inflasi dan Kurs Rupiah Tahun 2011-2017. Penentuan sampel menggunakan metode sensus dengan mengambil seluruh populasi. Penelitian ini menggunakan data sekunder, time series dengan jumlah data sebanyak 72 periode. Analisis data pada penelitian ini menggunakan analisis regresi linier berganda, uji statistik t, uji statistik F, dan uji koefisien determinasi $\left(\mathrm{R}^{2}\right)$ dengan bantuan program komputer SPSS versi 17. Hasil analisis ini menunjukan bahwa variabel Kurs Rupiah berpengaruh negatif secara signifikan terhadap Indeks Saham Syariah Indonesia. Namun variabel FED Rate, Harga Minyak Dunia, BI Rate, dan Inflasi tidak memiliki pengaruh yang signifikan terhadap Indeks Saham Syariah Indonesia.
\end{abstract}

Kata Kunci : Indeks Saham Syariah Indonesia, FED Rate, Harga Minyak Dunia, BI Rate, Inflasi, Kurs Rupiah

\section{PENDAHULUAN}

Investasi syariah dipasar
modal memiliki peranan untuk
mengembangkan pangsa pasar
industri keuangan syariah di Indonesia. Mengingat saham syariah, obligasi syariah dan reksa dana syariah menjadi instrumen pendanaan dan pembiayaan yang lazim serta berkembang pesat saat ini . Salah satu alat ukur kinerja pasar modal syariah di Indonesia adalah Jakarta Islamic
Indeks (JII) yang terdiri dari 30 saham syariah terlikuid berdasarkan prinsip-prinsip syariah.Perkembangan pasar modal syariah di Indonesia semakin semarak dengan lahirnya Indeks Saham Syariah Indonesia (ISSI) yang diterbitkan oleh Bapepam-LK dan Dewan Syariah Nasional Majelis Ulama Indonesia (DSN-MUI) pada tanggal 12 Mei 2011. ISSI merupakan Indeks Saham Syariah yang terdiri dari seluruh 
saham yang tercatat dalam Bursa Efek Indonesia dan bergabung pada
Daftar Efek Syariah (Hartono, 2016: 161).

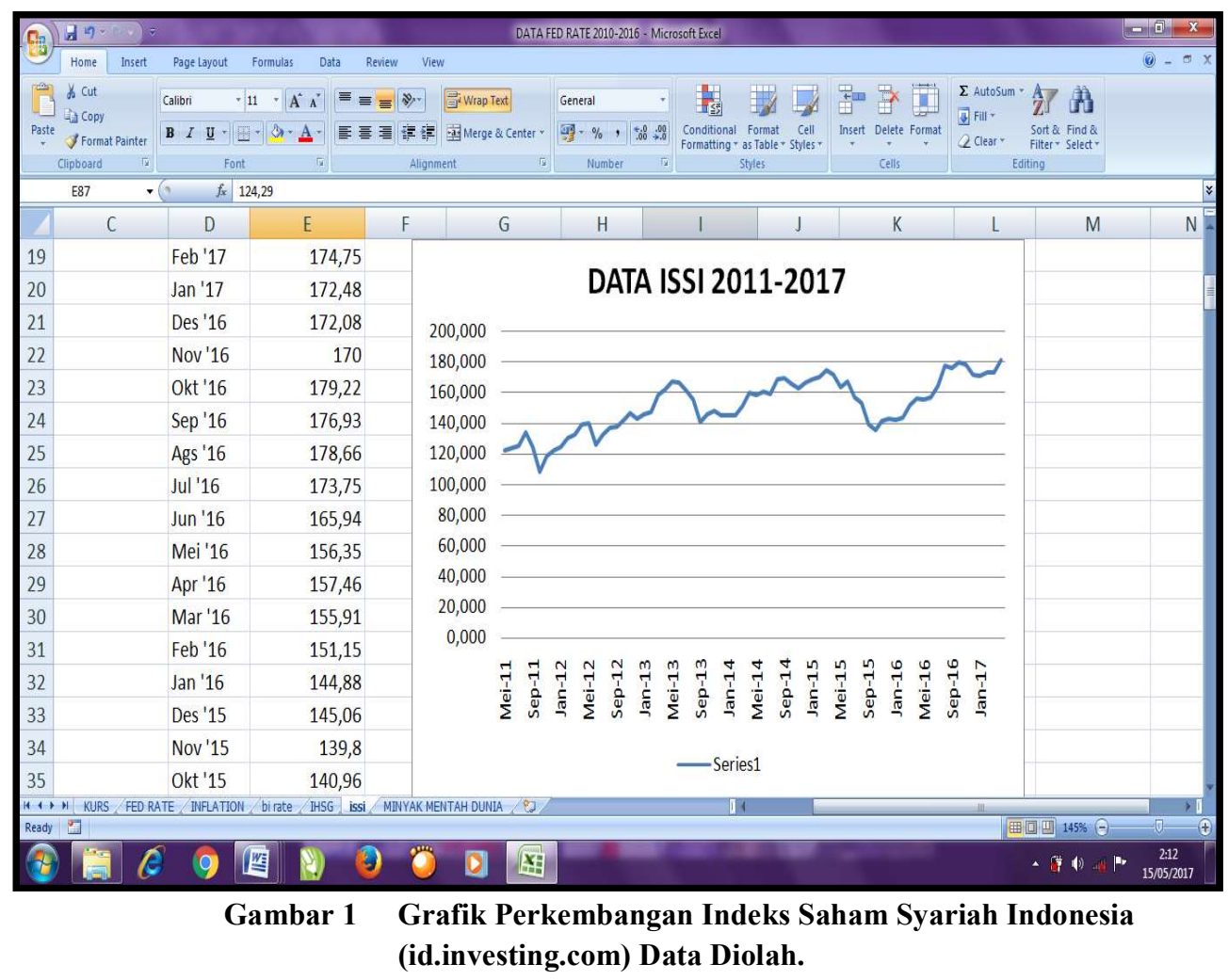

Peristiwa yang terjadi baik dalam lingkungan domestik maupun global sangat mempengaruhi kegiatan transaksi pasar modal. Reaksi pasar terhadap suatu peristiwa dapat dicerminkan dalam beberapa indikator seperti pergerakan harga saham dan jumlah transaksi (Surbakti ,2011) Pertengahan tahun 2013 nilai Rupiah terdepresiasi terhadap dolar AS hingga menembus $\mathrm{Rp} 12.000,00$ per dolar pada awal tahun 2014 setelah The FED menanggalkan penghentian stimulus Quantitative asing $(\mathrm{QE})$ secara bertahap mulai Januari 2014, sehingga menimbulkan ekspektasi penguatan dolar terhadap mata uang lainnya.
Kemudian, sejak Juni 2013 hingga akhir tahun 2013 tercatat Bank Indonesia (BI) menaikan suku bunga sebanyak 4 kali dengan total kenaikan 175 basis poin menjadi 7.50 persen dari 5.75 persen (sekarang BI Rate 7.75 persen). Pada saat yang sama pergerakan ISSI mengalami koreksi dari nilai tertinggi 169.81 pada Mei 2013 menjadi 143.70 pada akhir Desember 2014 (republika.co.id).

Awal tahun 2016 harga minyak mentah dunia yang terus menurun hingga mencapai kisaran 33,62 per barel. Sentimen negatif ini membuat para pelaku pasar modal dilanda kecemasan akibatnya aksi jual saham pun mendominasi laju indeks sektoral 
saham. Selanjutnya, pada akhir tahun 2016 setelah Bank Sentral Amerika Serikat, The Federal Reserve, menaikkan suku bunganya sebesar 25 basis poin. Kenaikan suku bunga The FED mengakibatkan penguatan dolar terhadap semua mata uang tak terkecuali nilai rupiah yang ikut terdepresiasi hingga menembus Rp. 13.349,00 per dolar. Pada saat yang sama pergerakan ISSI mengalami koreksi dari nilai terendah 144.88 pada Januari 2016 menjadi 172.42 pada akhir Januari 2017 (dream.co.id).

Berfluktuasinya

pergerakan indeks dalam industri pasar modal memang sudah seharusnya ditanggapi dengan serius olah para investor tentu hal tersebut dipengaruhi berbagai faktor. Menurut Syahrir (dalam Suciningtias, 2015) terdapat faktor-faktor penting yang mampu mempengaruhi perkembangan indeks syariah yaitu oleh beberapa variabel makro ekonomi dan moneter seperti Sertifikat Bank Indonesia Syariah, Inflasi, jumlah uang beredar (JUB), Nilai tukar dan lain - lain. Sedangkan faktor internal yang mampu mempengaruhi adalah seperti kondisi ekonomi nasional, keamanan, kondisi politik, kebijakan pemerintah dan lainlain. Sedangkan menurut Blanchard (dalam Wicaksono, 2017) menyatakan bahwa, banyak faktor yang dapat mempengaruhi pergerakan indeks saham, antara lain perubahan tingkat suku bunga bank sentral, keadaan ekonomi global, tingkat harga energi dunia, kestabilan politik suatu negara dan variabel lainnya .

FED Rate, atau suku bunga Federal Reserve, adalah tingkat suku bunga yang ditetapkan oleh The FED sebagai patokan bagi suku bunga pinjaman yang digunakan antar lembaga penyimpanan keuangan di seluruh AS dalam waktu semalam

(www.fred.stlouisfed.org).

Ketika FED Rate naik, maka bunga pinjaman maupun simpanan di bank dan lembaga keuangan lainnya juga bisa naik, maka itu akan menarik minat investor dari seluruh dunia untuk menempatkan dana mereka dalam bentuk tabungan/deposito di Amerika.

Harga minyak dunia merupakan salah satu variabel terpenting yang dapat mempengaruhi berbagai sektor rill dan fiskal. Dimana kenaikan harga minyak dunia akan menjadikan meningkatnya harga komoditas lainnya diseluruh dunia yang mampu meningkatkan tekanan inflasi. Sedangkan negara pengekspor minyak, kenaikan harga minyak mentah dunia merupakan keuntungan tersendiri bagi perusahaan. Karena harga minyak yang sedang tinggi membuat para investor cenderung menginvestasikan dananya ke berbagai sektor komoditi minyak dan pertambangannya. Namun ketika harga minyak dunia turun, para investor akan menjual sahamnya untuk mendapatkan keuntungan (Rusbariand, 2012).

BI Rate merupakan
tingkat suku bunga yang


ditetapkan oleh BI sebagai patokan bagi suku bunga pinjaman maupun simpanan bagi bank dan atau lembaga-lembaga keuangan di seluruh Indonesia (bi.go.id). Jika BI Rate mengalami kenaikan akan berdampak pada naiknya biaya transaksi perusahaan dalam proyek investasi, sebagian besar investor memilih berinvestasi pada instrument lain, maka harga saham di BEI menurun.

Variabel inflasi diartikan sebagai meningkatnya hargaharga secara umum dan terus menerus. Kenaikan harga dari satu atau dua barang saja tidak dapat disebut inflasi kecuali bila kenaikan itu meluas (atau mengakibatkan kenaikan harga) pada barang lainnya (bi.go.id). Inflasi dapat memiliki dampak positif atau negatif terhadap perekonomian tergantung dari tinggi rendah inflasi. Tingkat inflasi di Indonesia yang selalu mengalami fluktuasi tidak menutup kemungkinan akan mempengaruhi tingkat investasi dipasar modal Indonesia tidak terkecuali pada Indeks Saham Syariah Indonesia (ISSI) (Mulyani, 2014)

Kurs Rupiah merupakan nilai tukar mata uang Amerika Serikat dengan Indonesia. Melemahnya nilai Rupiah memicu naiknya harga komoditas, termasuk barangbarang produksi. Tentunya hal ini berdampak pada meningkatnya biaya produksi, dan menurunnya laba perusahaan. Turunnya laba perusahaan akan berpengaruh pada kebijakan deviden, terutama deviden kas dan hal ini daya tarik investor. Menurunnya minat investor terhadap saham dapat berdampak pada menurunnya harga saham, sehingga Indeks Saham Syariah Indonesia juga mengalami (Rusbariand, 2012).

Berdasarkan penelitian terdahulu yang telah diuraikan diatas, peneliti ingin menguji lebih lanjut untuk mengetahui pengaruh FED Rate, Harga Minyak Dunia, BI Rate, Inflasi dan Kurs Rupiah Terhadap Indeks Saham Syariah Indonesia (ISSI) Periode Tahun 2011-2017.

\section{METODE}

Penelitian ini adalah penelitian kuantitatif, pada penelitian kuantitatif maka yang diteliti terkait dengan frekuensi atau penyebaran suatu gejala atau frekuensi adanya hubungan antara gejala dengan faktorfaktor lain dalam suatu komunitas tertentu (Wiyono, 2011:52). Penelitian ini menganalisis pengaruh FED Rate, Harga Minyak Dunia, BI Rate, Inflasi, dan Kurs Rupiah yang diperkirakan mampu mempengaruhi pergerakan indeks harga saham yang terdapat di Indeks Saham Syariah Indonesia (ISSI) pada periode Mei 2011April 2017. Data yang dianalisis dalam penulisan ini adalah data sekunder, yang bersumber dari website yang berkaitan dengan variabel penelitan antara lain Indeks Saham Syariah Indonesia (ISSI) dan harga minyak mentah melalui www.investing.com , situs resmi Bank Indonesia (www.bi.go.id) digunakan untuk memperoleh data BI RATE, dan Inflasi, situs resmi Kementerian Perdagangan Republik Indonesia 
(www.kemendag.go.id) untuk data Kurs Rupiah. Sedangkan data FED Rate diperoleh dari www.fred.stlouisfed.org.

Populasi penelitian ini adalah data Indeks Saham Syariah Indonesia, FED Rate, Harga Minyak Dunia, BI Rate, Inflasi dan Kurs Rupiah Tahun 2011-2017. Penentuan sampel menggunakan metode sensus dengan mengambil seluruh populasi. Penelitian ini menggunakan data sekunder, time series dengan jumlah data sebanyak 72 periode

Metode yang digunakan dalam pengumpulan data untuk melakukan penelitian ini adalah melalui Website dan Studi Perpustakaan.

Metode analisis yang digunakan dalam penelitian ini adalah metode analisis Regresi linier berganda. Analisis ini digunakan untuk mengetahui seberapa besar pengaruh dari beberapa variabel independen terhadap variabel dependen. Sebelum melakukan analisis Regresi linier berganda terlebih dahulu melakukan Uji Asumsi klasik. Uji asumsi klasik yang digunakan terdiri dari $\mathrm{Uji}$ Normalitas,Uji Multikolinearitas, Uji Autokorelasi dan Uji Heteroskedastisitas Analisis regresi linear berganda digunakan untuk menguji pengaruh antara FED Rate, Harga Minyak Dunia, Bi Rate, Inflasi Dan Kurs Rupiah terhadap ISSI. Analisis data pada penelitian ini menggunakan bantuan program komputer SPSS versi 17. Untuk mengetahui seberapa berpengaruh variabel independen terhadap variabel dependen digunakan persamaan regresi sebagai berikut:

$$
\mathbf{Y}=\mathbf{a}+\mathbf{b}_{1} \mathbf{X}_{1}+\mathbf{b}_{2} \mathbf{X}_{2}+\mathbf{b}_{3} \mathbf{X}_{3}+\mathbf{b}_{4} \mathbf{X}_{4}+\mathbf{b}_{5} \mathbf{X}_{5}+\mathrm{e}
$$

Keterangan :

$\mathrm{Y}=$ Indeks Saham Syariah Indonesia

$\mathrm{a}=$ Konstanta

$\mathrm{b}_{1}, \mathrm{~b}_{2}, \mathrm{~b}_{3}, \mathrm{~b}_{4}, \mathrm{~b}_{5}=$ Koefisien Regresi

untuk $\mathrm{X}_{1}, \mathrm{X}_{2}, \mathrm{X}_{3}, \mathrm{X}_{4}$ dan $\mathrm{X}_{5}$

$\mathrm{X}_{1}=$ FED Rate

$\mathrm{X}_{2}=$ Harga Minyak Dunia

$\mathrm{X}_{3}=$ BI Rate

$\mathrm{X}_{4}=$ Inflasi

$\mathrm{X}_{5}=$ Kurs Rupiah

$\mathrm{e}=$ Faktor lain ( Faktor Pengganggu)

\section{HASIL}

Berdasarkan hasil penelitian maka diperoleh hasil Uji Asumsi Klasik sebagai berikut ini:

a. Uji Autokorelasi

Hasil dari uji Durbin

Watson menunjukkan bahwa nilai Durbin Watson sebesar 0,357 sedangkan nilai pada tabel Durbin Watson $\mathrm{N}=72$, $\mathrm{K}=5$ terletak pada $\mathrm{dU}=$ 1,7688 dan dL sebesar 1,4732. Nilai uji DW tersebut berada pada daerah dengan adanya masalah autokorelasi dimana nilai Durbin Waston $(0,357)<$ dL (1.4732) itu berarti bahwa ada korelasi positif.

Pada penelitian ini yang menggunakan data time series kemungkinan terjadinya gangguan autokorelasi memang besar. Adanya gangguan autokorelasi tersebut perlu solusi untuk menangani agar tidak ada masalah autokorelasi dalam pemodelan persamaan regresi dipenelitian ini. Cara untuk mengatasi gangguan 
autokorelasi dalam penelitian menggunakan transformasi dengan bentuk The First difference Method (perbedaan

1) (Suciningtias, 2015).

Tabel 1

\section{Hasil Uji Autokorelasi}

Model Summary ${ }^{\circ}$

\begin{tabular}{lrrrrr}
\hline Model & R & R Square & $\begin{array}{c}\text { Adjusted R } \\
\text { Square }\end{array}$ & $\begin{array}{c}\text { Std. Error of the } \\
\text { Estimate }\end{array}$ & Durbin-Watson \\
\hline 1 & $.620^{\mathrm{a}}$ & .384 & .337 & 4.60975 & 1.977 \\
\hline
\end{tabular}

Hasil dari uji statistik Durbin Watson setelah menggunakan data hasil transformasi the first difference menunjukkan bahwa nilai Durbin Watson sebesar 1,977 sedangkan nilai tabel Durbin Watson pada $\mathrm{N}=71, \mathrm{~K}=5$ pada $\mathrm{dU}$ $=1,7685$ dan $\mathrm{dL}$ sebesar 1,4685. Nilai tersebut berada pada daerah $\mathrm{dU}<\mathrm{d}<4-\mathrm{dU}$ berarti tidak ada lagi masalah autokorelasi positif atau negatif dan model regresi layak digunakan.

b. Uji Normalitas

Hasil uji normalitas dapat dilihat melalui tabel Kolmogorov-Smirnov test. Hasil uji sebagai berikut:

Tabel 2

Hasil Uji Normalitas

One-Sample Kolmogorov-Smirnov Test

\begin{tabular}{llr}
\hline \multicolumn{2}{c}{ One-Sample Kolmogorov-Smirnov Test } \\
\hline & & $\begin{array}{c}\text { Unstandardized } \\
\text { Residual }\end{array}$ \\
\hline Normal Parameters ${ }^{\mathrm{a}, \mathrm{b}}$ & Mean & 71 \\
& Std. Deviation & .0000000 \\
Most Extreme Differences & Absolute & 4.44206167 \\
& Positive & .116 \\
Kolmogorov-Smirnov Z & Negative & .069 \\
Asymp. Sig. (2-tailed) & & -.116 \\
\hline
\end{tabular}

a. Test distribution is Normal.

Hasil penelitian uji normalitas dengan Kolmogorov - Smirnov test sebesar 0,975 dengan signifikansi sebesar 0,298. Nilai signifikansi yang lebih besar dari 0,05 itu berarti menunjukkan bahwa model regresi memiliki residual yang berdistribusi normal.

c. Uji Multikolinearitas Berdasarkan hasil uji multikolinearitas pada Tabel 3, dapat disimpulkan bahwa: 
Tabel 3

Hasil Uji Multikolinearitas

\begin{tabular}{lll}
\multicolumn{3}{c}{ Coefficients $^{\text {a }}$} \\
\hline & \multicolumn{2}{c}{ Collinearity Statistics } \\
Model & Tolerance & VIF \\
\hline 1 (Constant) & & \\
D_FED_RATE & .962 & 1.039 \\
D_HARGA_MINYAK_DUNIA & .951 & 1.051 \\
D_BI_RATE & .907 & 1.102 \\
D_INFLASI & .927 & 1.079 \\
D_KURS_RUPIAH & .933 & 1.072 \\
\hline a. Dependent Variable: D_ISSI & &
\end{tabular}

Data penelitian variabel independen maupun dependen bebas dari multikolinearitas yang ditunjukkan dengan nilai tolerance dari masing masing variabel lebih besar dari 0,10 dan nilai VIF lebih kecil dari 10.

d. Uji Heterokedastisitas

Uji Heteroskedastisitas dilakukan memplotkan grafik antara SRESID (Studentized Residual) untuk Y dengan ZPRED (Standardized Predicted Value) untuk X di mana gangguan heteroskedastisitas akan tampak dengan adanya pola tertentu pada grafik. Berikut adalah uji heteroskedastisitas pada model penelitian ini :

Gambar 2

\section{Hasil Uji Heterokedastisitas}

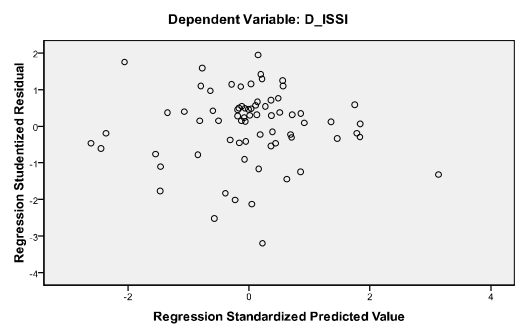

Dari output di atas dapat diketahui bahwa titiktitik tidak membentuk pola yang jelas, dan titik-titik menyebar di atas dan di bawah angka 0 pada sumbu Y. Jadi dapat disimpulkan bahwa tidak terjadi masalah heteroskedastisitas dalam model regresi.

\section{Hasil Pengujian Regresi Linear Berganda}

Berdasarkan

pengolahan data dengan menggunakan program SPSS 
diperoleh hasil sebagai berikut :

Tabel 4

Hasil Uji Regresi Linear Berganda

\begin{tabular}{|c|c|c|c|c|c|c|}
\hline \multicolumn{7}{|c|}{ Coefficients $^{a}$} \\
\hline & & \multicolumn{2}{|c|}{$\begin{array}{l}\text { Unstandardized } \\
\text { Coefficients }\end{array}$} & $\begin{array}{l}\text { Standardized } \\
\text { Coefficients }\end{array}$ & \multirow[b]{2}{*}{$\mathrm{t}$} & \multirow[b]{2}{*}{ Sig. } \\
\hline \multicolumn{2}{|c|}{ Model } & $\mathrm{B}$ & $\begin{array}{l}\text { Std. } \\
\text { Error }\end{array}$ & Beta & & \\
\hline 1 & (Constant) & 1.266 & .602 & & 2.101 & .040 \\
\hline & D_FED_RATE & 4.732 & 15.961 & .029 & .296 & .768 \\
\hline & $\begin{array}{l}\text { D_HARGA_MINYAK_ } \\
\text { DUNIA }\end{array}$ & -.068 & .094 & -.072 & -.726 & .470 \\
\hline & D_BI_RATE & -5.303 & 2.708 & -.200 & -1.958 & .055 \\
\hline & D_INFLASI & -.819 & .822 & -.101 & -.997 & .323 \\
\hline & D_KURS_RUPIAH & -.010 & .002 & -.522 & -5.182 & .000 \\
\hline
\end{tabular}

Model persamaan regresi yang dibentuk dari hasil penelitian pada tabel 4 adalah sebagai berikut :

$\mathrm{Y}=\mathrm{a}+\mathrm{b}_{1} \mathrm{X}_{1}+\mathrm{b}_{2} \mathrm{X}_{2}+\mathrm{b}_{3} \mathrm{X}_{3}+\mathrm{b}_{4} \mathrm{X}_{4}+\mathrm{b}_{5} \mathrm{X}_{5}+\mathrm{e}$ $\mathrm{Y}=1,266+4,732 \mathrm{X}_{1}-0,068 \mathrm{X}_{2}-5,303 \mathrm{X}_{3}-$ $0,819 \mathrm{X}_{4}-0,010 \mathrm{X}_{5}+\mathrm{e}$

Keterangan :

\begin{tabular}{|c|c|c|}
\hline $\mathrm{Y}$ & $=$ & Indeks Saham \\
\hline & & $\begin{array}{l}\text { Syariah Indonesia } \\
\text { (ISSI) }\end{array}$ \\
\hline $\mathrm{a}$ & $=$ & Konstanta \\
\hline $\mathrm{b}_{1}, \mathrm{~b}_{2}, \mathrm{~b}_{3}, \mathrm{~b}_{4}, \mathrm{~b}_{5}$ & $=$ & $\begin{array}{l}\text { Koefisien Regresi } \\
\text { untuk } X_{1}, X_{2}, X_{3}, X_{4} \\
\text { dan } X_{5}\end{array}$ \\
\hline$X_{1}$ & $=$ & FED Rate \\
\hline $\mathrm{X}_{2}$ & $=$ & Harga Minyak Dunia \\
\hline $\mathrm{X}_{3}$ & $=$ & BI Rate \\
\hline $\mathrm{X}_{4}$ & $=$ & Inflasi \\
\hline $\mathrm{X}_{5}$ & $=$ & Kurs Rupiah \\
\hline e & $=$ & Error of Estimation \\
\hline
\end{tabular}

Berdasarkan persamaan regresi diatas maka nilai koefisien dapat diinterpretasikan sebagai berikut:

- Pada nilai Konstanta (a) sebesar 1,266 menunjukkan bahwa Indeks Syariah Saham Indonesia akan konstan apabila variabel FED Rate, Harga Minyak Dunia, BI Rate, Inflasi, Kurs Rupiah sama dengan nol atau tidak ada.
- Pada nilai koefisien regresi FED Rate $\left(\mathrm{X}_{1}\right)$ sebesar 4,732 berarti jika FED Rate meningkat $1 \%$ maka akan meningkatkan nilai Indeks Saham Syariah Indonesia (ISSI) sebesar 4,732 poin dengan asumsi variabel lain dianggap konstant.

- Nilai koefisien regresi Harga Minyak Dunia $\left(\mathrm{X}_{2}\right)$ sebesar 0,068 karena variabel bertanda negatif berarti jika Harga minyak dunia meningkat $1 \%$ maka akan menurunkan nilai Indeks Saham Syariah Indonesia (ISSI) sebesar -0,068 poin dengan asumsi variabel lain dianggap konstant.

- Nilai koefisien regresi BI Rate $\left(\mathrm{X}_{3}\right)$ sebesar -5,303 dimana nilai tersebut bertanda negatif yang berarti jika BI Rate meningkat $1 \%$ maka akan menurunkan nilai Indeks Saham Syariah Indonesia (ISSI) sebesar -5,303 poin dengan asumsi variabel lain dianggap konstant.

- Nilai koefisien regresi Inflasi sebesar -0,819 $\left(\mathrm{X}_{4}\right)$ dimana nilai 
tersebut bertanda negatif yang berarti jika tingkat Inflasi meningkat $1 \%$ maka akan menurunkan nilai Indeks Saham Syariah Indonesia (ISSI) sebesar $-0,819$ poin dengan asumsi variabel lain dianggap konstant.

- Nilai koefisien regresi Kurs Rupiah $\left(\mathrm{X}_{5}\right)$ sebesar $-0,010$ dimana nilai tersebut bertanda negatif yang berarti jika tingkat Kurs Rupiah meningkat $1 \%$ maka akan menurunkan nilai Indeks Saham Syariah Indonesia (ISSI) sebesar -0,010 poin dengan asumsi variabel lain dianggap konstant.

\section{Hasil Pengujian Hipotesis}

a. Uji t (Uji Parsial)

Berdasarkan hasil uji t (uji parsial) pada Tabel 5 dibawah ini dapat disimpulkan bahwa:

Tabel 5

Hasil Uji Statistik t

\begin{tabular}{|c|c|c|c|c|c|c|}
\hline \multicolumn{7}{|c|}{ Coefficients $^{a}$} \\
\hline & \multirow{2}{*}{ Model } & \multicolumn{2}{|c|}{$\begin{array}{l}\text { Unstandardized } \\
\text { Coefficients }\end{array}$} & \multirow{2}{*}{$\begin{array}{c}\text { Standardized } \\
\text { Coefficients } \\
\text { Beta }\end{array}$} & \multirow{2}{*}{$\mathrm{t}$} & \multirow{2}{*}{ Sig. } \\
\hline & & B & $\begin{array}{l}\text { Std. } \\
\text { Error }\end{array}$ & & & \\
\hline \multirow[t]{6}{*}{1} & (Constant) & 1.266 & .602 & & 2.101 & .040 \\
\hline & D_FED_RATE & 4.732 & 15.961 & .029 & .296 & .768 \\
\hline & $\begin{array}{l}\text { D_HARGA_MINYAK_ } \\
\text { DUNIA }\end{array}$ & -.068 & .094 & -.072 & -.726 & .470 \\
\hline & D_BI_RATE & -5.303 & 2.708 & -.200 & -1.958 & .055 \\
\hline & D_INFLASI & -.819 & .822 & -.101 & -.997 & .323 \\
\hline & D_KURS_RUPIAH & -.010 & .002 & -.522 & -5.182 & .000 \\
\hline
\end{tabular}

a. Dependent Variable: D_ISSI

1) Pengaruh FED Rate terhadap Indeks Saham Syariah Indonesia (ISSI)

Dari hasil pengujian regresi diatas dapat dilihat nilai $F E D$ Rate sebesar 0,296 dengan signifikansi sebesar 0,768 . Nilai sigifikansi tersebut lebih besar dari 0,05 atau Sig $\mathrm{t}=0,768>$ 0,05 . Nilai $t$ tabel sebesar $1,99714 \quad(\mathrm{df}=71-5-1)$. Dibandingkan dengan $\mathrm{t}$ tabel ternyata thitung lebih kecil dari t tabel atau $(0,296<1,99714)$ .Hal ini berarti bahwa FED Rate tidak memiliki pengaruh yang signifikan terhadap Indeks
Saham Syariah Indonesia (ISSI) dengan arah positif.

2) Pengaruh Harga Minyak Dunia terhadap Indeks Saham Syariah Indonesia (ISSI)

Dari hasil pengujian regresi diatas dapat dilihat nilai Harga Minyak Dunia sebesar -0,726 dengan signifikansi sebesar 0,470 . Nilai sigifikansi tersebut lebih besar dari 0,05 atau Sig t $=0,470>0,05$. Nilai $\mathrm{t}$ tabel sebesar 1,99714 (df=71-5-1). Dibandingkan dengan $t$ tabel ternyata thitung lebih kecil dari $\mathrm{t}$ tabel atau $(0,726<1,99714)$. Hal ini berarti bahwa Harga 
Minyak Dunia tidak memiliki pengaruh yang signifikan terhadap Indeks Saham Syariah Indonesia (ISSI) dengan arah negatif.

3) Pengaruh BI Rate terhadap Indeks Saham Syariah Indonesia (ISSI)

Dari hasil pengujian regresi diatas dapat dilihat nilai BI Rate sebesar -1,958 dengan signifikansi sebesar 0,055 . Nilai sigifikansi tersebut lebih besar dari 0,05 atau $\operatorname{Sig} \mathrm{t}=0,055>$ 0,05 . Dibandingkan dengan $t$ tabel ternyata $\mathrm{t}$ hitung lebih kecil dari $\mathrm{t}$ tabel atau $(1,958$ $<1,99714$ ). Hal ini berarti bahwa BI Rate tidak memiliki pengaruh yang signifikan terhadap Indeks Saham Syariah Indonesia (ISSI) dengan arah negatif.

4) Pengaruh Inflasi terhadap Indeks Saham Syariah Indonesia (ISSI)

Dari hasil pengujian regresi diatas dapat dilihat nilai Inflasi sebesar $\quad-0,977$ dengan signifikansi sebesar 0,323 . Nilai sigifikansi tersebut lebih besar dari 0,05 atau Sig $t=0,323>$
0,05 . Dibandingkan dengan $\mathrm{t}$ tabel ternyata $\mathrm{t}$ hitung lebih kecil dari t tabel atau $(0,977$ $<1,99714)$. Hal ini berarti bahwa Inflasi tidak memiliki pengaruh yang signifikan terhadap Indeks Saham Syariah Indonesia (ISSI) dengan arah negatif.

5) Pengaruh Kurs Rupiah terhadap Indeks Saham Syariah Indonesia (ISSI)

Dari hasil pengujian regresi diatas dapat dilihat nilai Kurs Rupiah sebesar -5,182 dengan signifikansi sebesar 0,000. Nilai sigifikansi tersebut lebih kecil dari 0,05 atau Sig $\mathrm{t}=0,000<$ 0,05 . Dibandingkan dengan $t$ tabel ternyata $\mathrm{t}$ hitung lebih besar dari t tabel atau $(5,182>$ 1,99714). Hal ini berarti bahwa Kurs Rupiah memiliki pengaruh yang signifikan terhadap Indeks Saham Syariah Indonesia (ISSI) dengan arah negatif.

b. Uji F (Uji Simultan)

Berdasarkan hasil uji $\mathrm{F}$ (uji simultan) pada Tabel 6, dibawah ini dapat disimpulkan bahwa:

Tabel 6

Hasil Uji Statistik F ANOVA $^{\mathrm{b}}$

\begin{tabular}{|c|c|c|c|c|c|c|}
\hline Model & & Sum of Squares & $\mathrm{df}$ & Mean Square & $F$ & Sig. \\
\hline \multirow[t]{3}{*}{1} & Regression & 862.095 & 5 & 172.419 & 8.114 & $.000^{\mathrm{a}}$ \\
\hline & Residual & 1381.234 & 65 & 21.250 & & \\
\hline & Total & 2243.329 & 70 & & & \\
\hline
\end{tabular}

a. Predictors: (Constant), D_KURS_RUPIAH, D_FED_RATE, D_HARGA_MINYAK_DUNIA, D_INFLASI, D_BI_RATE

b. Dependent Variable: D_ISSI

Diketahui $\mathrm{F}$ hitung sebesar 8,114 dengan tingkat signifikansi menggunakan 0,000 . Nilai sigifikansi tersebut lebih kecil dari 0,05 atau Sig $\mathrm{t}=0,000<$ 0,05 dan nilai $F$ tabel sebesar 
$2,24 \quad(\mathrm{dk}=5),(\mathrm{dk}=71-5-1)$.

Dibandingkan dengan $F$ tabel ternyata nilai $\mathrm{F}$ hitung lebih besar dari $F$ tabel atau $(8,114>2,24)$, maka Ho ditolak yang artinya ada pengaruh signifikan antara FED Rate, Harga Minyak Dunia, BI Rate, Inflasi dan Kurs Rupiah secara bersama-sama terhadap
Indeks Saham Syariah Indonesia (ISSI).

c. Menghitung Koefisien Determinasi $\left(\mathrm{R}^{2}\right)$

Berdasarkan hasil uji Koefisien Determinasi $\left(\mathrm{R}^{2}\right)$ pada tabel 4.8 dibawah ini diketahui:

Tabel 7

Hasil Uji Koefisien Determinasi $\left(\mathbf{R}^{2}\right)$

Model Summary ${ }^{\mathrm{b}}$

\begin{tabular}{|c|c|c|c|c|}
\hline Model & $\mathrm{R}$ & R Square & $\begin{array}{l}\text { Adjusted R } \\
\text { Square }\end{array}$ & $\begin{array}{c}\text { Std. Error of the } \\
\text { Estimate }\end{array}$ \\
\hline 1 & $.620^{\mathrm{a}}$ & .384 & .337 & 4.60975 \\
\hline
\end{tabular}

Nilai Adjusted $R$ Square sebesar 0,337 atau 33,7 \%. Hal ini berarti sebesar 33,7\% variabel Indeks Saham Syariah Indonesia dapat dipengaruhi oleh FED Rate, Harga Minyak Dunia, BI Rate, Inflasi dan Kurs Rupiah, sedangkan sisanya $61,3 \%$ Indeks Saham Syariah Indonesia dipengaruhi oleh variabel lainnnya. Dilihat dari nilai Adjusted $R$ Square bahwa pengaruh independen terhadap dependen tergolong lemah.

\section{PEMBAHASAN}

1. Pengaruh FED Rate Terhadap Indeks Saham Syariah Indonesia (ISSI)

Hasil pengujian regresi diketahui bahwa FED Rate tidak berpengaruh terhadap Indeks Saham Syariah Indonesia. Menurut Wijayaningsih (2016) tidak berpengaruhnya FED Rate karena ada keragaman informasi yang menyebabkan perbedaan pengambilan keputusan yang dilakukan investor. Keragaman informasi ini karena adanya investor yang tidak hanya melihat perubahan FED Rate saja, namun juga melihat selisish BI Rate dengan FED Rate sesuai teori paritas suku bunga.

Hasil penelitian ini mendukung penelitian Wijayaningsih (2016) dan Wicaksono (2017) yang mengungkapkan bahwa FED Rate tidak memiliki pengaruh terhadap indeks harga saham. Akan tetapi bertolak belakang dengan penelitian Surbakti (2011) dan Gom (2015) yang menunjukan adanya pengaruh FED Rate terhadap indeks harga saham.

\section{Pengaruh Harga Minyak Dunia Terhadap Indeks Saham Syariah Indonesia (ISSI) \\ Hasil pengujian regresi
diketahui bahwa Harga}


Minyak Dunia berpengaruh negatif namun tidak signifikan terhadap Indeks Saham Syariah Indonesia. Hal tersebut berarti harga minyak dunia tidak dapat mempengaruhi secara kuat perubahan dari pergerakan Indeks Saham Syariah Indonesia.

$$
\text { Lonjakan harga }
$$

minyak akan memberikan keuntungan tersendiri bagi perusahaan perusahaan Indonesia yang bergerak disektor komoditi minyak dan pertambangan karena mampu menarik bagi investor untuk menanamkan dana investasinya diberbagai sektor komoditi minyak atau pertambangan pada pasar modal Indonesia (Suciningtias, 2015). Namun ketidakstabilan Harga Minyak Dunia juga berdampak negatif bagi perusahaan yang menggunakan minyak sebagai bahan bakar karena lonjakan Harga minyak mentah dunia akan membuat harga bahan bakar pendukung produksi menjadi naik dan memberikan pengaruh meningkatnya biaya produksi dan menurunnya laba (Daniel, 2014) . Penurunan kemampuan menghasilkan laba dan membagikan dividen akan membuat minat investor menjadi rendah, dan investor perusahaan yang bersangkutan akan cenderung untuk menjual sahamnya sehingga harga saham turun hal ini juga berimbas pada menurunnya Indeks Saham Syariah Indonesia.

\begin{abstract}
Akan tetapi dari hasil penelitian ini yang menyatakan bahwa harga minyak dunia tidak mampu mempengaruhi Indeks Saham Syariah Indonesia (ISSI) secara signifikan. Dimana perubahan naik turunnya harga minyak dunia dalam kenyataan tidak mampu mempengaruhi sikap investor.

Hasil penelitian ini sesuai dengan penelitian Suciningtias (2015) yang menyatakan Harga Minyak Dunia tidak berpengaruh terhadap Indeks Saham Syariah Indonesia. Namun pada penelitian Muhammad Syafii dkk (2013) respon negatif ditunjukan FTSE Bursa Malaysia Hijrah Shariah Index (FHSI) dan Jakarta Islamic Indek (JII) terhadap guncangan yang terjadi pada Harga minyak (OIL).
\end{abstract}

\section{Pengaruh BI Rate Terhadap Indeks Saham Syariah Indonesia (ISSI)}

Hasil pengujian regresi diketahui bahwa BI Rate berpengaruh negatif namun tidak signifikan terhadap Indeks Saham Syariah Indonesia. Hal tersebut berarti BI Rate tidak dapat mempengaruhi secara kuat perubahan dari pergerakan Indeks Saham Syariah Indonesia.

Pengaruh negatif yang ditunjukan sejalan dengan pendapat Tandellin (dalam Rachmawati, 2015) bahwa suku bunga yang tinggi merupakan sinyal negatif pada harga saham dimana investor 
akan cenderung tertarik berinvestasi dan memindahkan investasinya dalam bentuk tabungan atau deposito.

Tetapi pada hasil uji hipotesis, menunjukkan bahwa variabel BI Rate berpengaruh tidak signifikan terhadap Indeks Saham Syariah Indonesia. Hal ini terjadi karena saham-saham yang tergabung dalam Indeks Saham Syariah Indonesia telah melalui proses screening dimana usaha yang dilakukan perusahaan tidak berkonsep ribawi; hutang berbasis bunga dibatasi yaitu tidak boleh lebih dari $45 \%$; pendapatan bunga tidak boleh lebih dari $10 \%$. Hal ini menjadi salah satu keunggulan produk syariah dimana perubahan pada suku bunga tidak akan membawa dampak yang sangat berarti pada indeks saham syariah (Rachmawati, 2015)

Hasil penelitian ini
bertentangan penelitian yang dilakukan Mulyani (2014) dan Ardana (2016) yang menyatakan $B I$ Rate berpengaruh negatif secara signifikan terhadap Jakarta Islam Indeks dan ISSI. Namun sejalan dengan hasil penelitian Rachmawati (2015) yang menyatakan BI Rate tidak berpengaruh pada Indeks Saham Syariah Indonesia.

\section{Pengaruh Inflasi Terhadap Indeks Saham Syariah Indonesia (ISSI)}

Hasil pengujian regresi diketahui bahwa Inflasi berpengaruh negatif namun tidak signifikan terhadap
Indeks Saham Syariah

Indonesia. Hal tersebut berarti Inflasi tidak dapat mempengaruhi secara kuat perubahan dari pergerakan Indeks Saham Syariah Indonesia. Tandelilin (dalam Rachmawati , 2015) mengatakan bahwa peningkatan inflasi secara relatif akan membawa sinyal negatif bagi pemodal di pasar modal. Kenaikan inflasi menyebabkan konsumsi riil masyarakat berkurang karena nilai uang yang dipegang masyarakat menjadi turun. Akibat naiknya harga barang dan jasa maka masyarakat lebih memilih untuk menahan kebutuhan konsumsi mereka atau setidaknya menghemat pengeluaran. Dengan pengurangan konsumsi oleh masyarakat maka penjualan perusahaan otomatis akan berkurang sehingga keuntungan yang mereka dapatkan pun turut berkurang. Inflasi juga mempengaruhi biaya operasional dan biaya produksi sehingga menurunkan profitabilitas perusahaan.

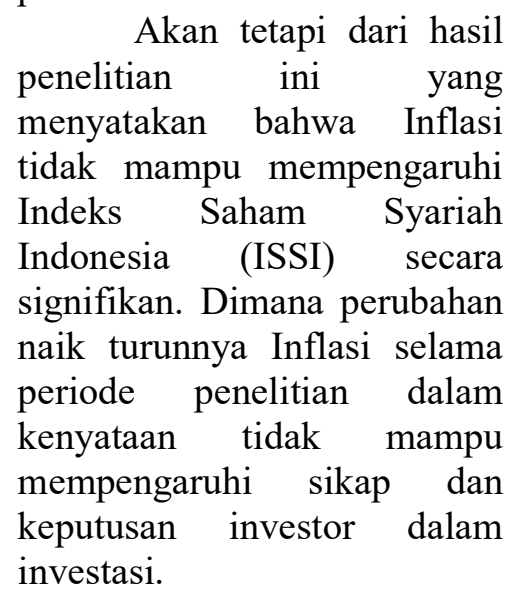

Akan tetapi dari hasil penelitian ini yang menyatakan bahwa Inflasi tidak mampu mempengaruhi Indeks Saham Syariah Indonesia (ISSI) secara signifikan. Dimana perubahan naik turunnya Inflasi selama periode penelitian dalam kenyataan tidak mampu mempengaruhi sikap dan investasi. 
sejalan penelitian ini sejalan dengan penelitian Rachmawati (2015) dan penelitian Ardana (2016) yang menyatakan Inflasi tidak berpengaruh terhadap Indeks Saham Syariah Indonesia. Berbanding terbalik dengan penelitian yang dilakukan Rusbariand (2012) dan Neny (2014) yang menyatakan Inflasi berpengaruh terhadap Jakarta Islam Indeks serta penelitian Sucinitias (2015) yang menyatakan Inflasi berpengaruh negatif terhadap Indeks Saham Syariah Indonesia.

\section{Pengaruh Kurs Rupiah Terhadap Indeks Saham Syariah Indonesia (ISSI)}

Hasil pengujian regresi mendapatkan bahwa Kurs Rupiah memiliki pengaruh negatif signifikan terhadap Indeks Saham Syariah Indonesia (ISSI). Hal ini berarti naik turunya Kurs Rupiah dapat mempengaruhi secara kuat perubahan Indeks Saham Syariah Indonesia.

Melemahnya nilai Rupiah memicu naiknya harga komoditas, termasuk barangbarang produksi. Tentunya hal ini berdampak pada meningkatnya biaya produksi, dan menurunnya laba perusahaan. Turunnya laba perusahaan akan berpengaruh pada kebijakan deviden, terutama deviden kas dan hal ini daya tarik investor. Menurunnya minat investor terhadap saham dapat berdampak pada menurunnya harga saham, sehingga Indeks
Saham Syariah Indonesia juga mengalami penurunan (Rusbariand, 2012). Hasil ini mendukung penelitian yang dilakukan Rusbariand (2012) dan Mulyani(2014) yang menyatakan Kurs Rupiah berpengaruh negatif terhadap Jakarta Islam Indeks serta Suciningtias(2015),

Rachmawati (2015) dan Ardana (2016) yang menyatakan Kurs Rupiah berpengaruh negatif terhadap Indeks Saham Syariah Indonesia. Namun bertentangan dengan penelitian Poetra (2016) yang menyatakan Kurs Rupiah tidak memiliki pengaruh terhadap Indeks Harga Saham.

\section{KESIMPULAN}

Berdasarkan hasil penelitian yang telah dilakukan maka pada penelitian ini dapat ditarik kesimpulan sebagai berikut:

1. FED Rate tidak berpengaruh terhadap Indeks Saham Syariah Indonesia.

2. Harga minyak dunia tidak berpengaruh terhadap Indeks Saham Syariah Indonesia.

3. BI Rate tidak berpengaruh terhadap Indeks Saham Syariah Indonesia.

4. Inflasi tidak berpengaruh terhadap Indeks Saham Syariah Indonesia.

5. Kurs Rupiah berpengaruh terhadap Indeks Saham Syariah Indonesia.

6. FED Rate, Harga minyak dunia, BI Rate, Inflasi Dan Kurs Rupiah berpengaruh terhadap Indeks Saham Syariah Indonesia. 


\section{DAFTAR PUSTAKA}

Ardana, Yudhistira. 2016. Analisis Pengaruh Variabel Makroekonomi Terhadap Indeks Saham Syariah Indonesia (Periode Mei 2011 - September 2015 Dengan Model Ecm). Jurnal Bisnis Dan Manajemen Volume 6 (1), April 2016 P-ISSN: 20872038; E-ISSN: 2461-1182. STMIK Pringsewu.

Bank Indonesia . 2017. Data BI Rate. http://www.bi.go.id/id/monete r/bi-rate/data/default.aspx.

Diakses Pada Tanggal 11 Juli 2017.

Bank Indonesia. 2017. Data BI 7 Day Repo Rate.

http://www.bi.go.id/ id/moneter/bi-7day-rr/data/ contents/default.aspx. Diakses Pada Tanggal 11 Juli 2017.

Bank Indonesia. 2017. Data Inflasi . http://www.bi.go.id/id/monete r/ inflasi/data/default.aspx. Diakses Pada Tanggal 11 Juli 2017.

Bank Indonesia 2017. Pengenalan Inflasi.

http://www.bi.go.id/id/monete $\underline{\mathrm{r} / \text { inflasi/pengenalan/contents/ }}$ default.aspx. Diakses Pada Tanggal 11 Juli 2017.

Bank Indonesia . 2017 . Penjelasan BI Rate. http://www.bi.go.id/id/monete r/ bi-rate/penjelasan/contents /default.aspx. Diakses Pada Tanggal 11 Juli 2017.

Budiawati, Arie D. 2016. Suku Bunga The Fed Naik, Indeks Syariah Rontok

.https://www.dream.co.id/dina r/suku-bunga-the-fed-naikindeks-syariah-rontok- 1612155.html. Diakses Pada Tanggal 11 Juli 2017.

Daniel, Chistoper. 2014. Goncangan Harga Minyak Dunia Terhadap Pasar Modal Indonesia. Institutional Repository Universitas Kristen Satya Wacana.

Data FED Rate. https://fred.stlouisfed.org/serie s/fedfunds. Diakses Pada Tanggal 11 Juli 2017

Data Indeks Saham Syariah Indonesia.

https://id.investing.com/indice s/idx-shariah-historical-data.

Diakses Pada Tanggal 11 Juli 2017

Data Harga Minyak Dunia. https://id.investing.com/comm odities/crude-oil-historicaldata. Diakses Pada Tanggal 11 Juli 2017

Fahmi, Irham Dan Yofi L. Hadi. 2011. Teori Portofolio Dan Analisis Investasi. Bandung : Cv. Alfabeta.

Forddanta, Dityasa H. 2016. Indonesia dan Malaysia Sepakati Pendirian Pasar Modal Berbasis Syariah. http://www.tribunnews.com/bi snis /2016/09/20/indonesiadan-malaysia-sepakatipendirian-pasar-modalberbasis-syariah. Diakses Pada Tanggal 11 Juli 2017.

Ghozali, Imam. 2016. Aplikasi Analisis Multivariete Dengan Program IBM SPSS 23. Semarang : Badan Penerbit Universitas Diponegoro.

Gom, Hotneri Gom. 2015. Analisis Pengaruh The Fed Rate, Indeks Dow Jones Dan Indeks Nikkei 225 Terhadap Indeks Harga Saham Gabungan (IHSG) Di Bursa Efek 
Indonesia (Bei) Periode 20082013. Jurnal Ekonomi Dan Keuangan Volume 1 No.8. Universitas Sumatera Utara.

Hartono, Jogiyanto. 2016. Teori Portofolio Dan Analisis Investasi. Yogyakarta: BPFEYogyakarta.

Kementrian Perdagangan Indonesia.2017. Data Kurs Rupiah. $\quad$ Error! Hyperlink reference not valid. Diakses Pada Tanggal 11 Juli 2017.

Latif, Syahid. 2016. Minyak Bikin Cemas, Bursa Syariah Berbalik Melemah. https://www.dream.co.id/dinar /minyak-bikin-cemas-bursasyariah-berbalik-melemah160121a.html. Diakses Pada Tanggal 11 Juli 2017.

Mulyani, Neny. 2014. Analisis Pengaruh Inflasi, Suku Bunga, Nilai Tukar Rupiah, Dan Produk Domestik Bruto Terhadap Jakarta Islamic Index. Jurnal Bisnis Dan Manajemen Eksekutif Vol. 1 No. 1, 2014. Universitas Terbuka.

Nurhayati, S. Dan Wasilah. 2014. Akuntansi Syariah Di Indonesia. Jakarta : Salemba Empat.

PSAK Nomor 13 Standart Akuntansi Keuangan Per 1 Oktober 2004 Tentang Investasi.

Poetra, Ronald Pratam. 2016. Pengaruh Inflasi, Harga Minyak Mentah, Suku Bunga, Nilai Tukar Rupiah Terhadap Indeks Harga Saham Gabungan (Ihsg) Di Bursa Efek Indonesia. Skripsi. Universitas Negeri Surabaya.

Purnawan, Irfan . 2017. Pengaruh Makroekonomi Domestik dan Global Terhadap Saham
Syariah.

http://www.republika.co.id/ber

ita/

koran/iqtishodia/15/01/22/nikj

kf10/pengaruh-

makroekonomi-domestik-danglobal-terhadap-saham-syariah . Diakses Pada Tanggal 11 Juli 2017.

Rachmawati, Martien. 2015. Faktor Makroekonomi Yang Mempengaruhi Pergerakan Harga Saham Pada Indeks Saham Syariah Indonesia (Issi) Di Bursa Efek Indonesia (BEI). Jurnal Jestt Vol. 2 No. 11. Universitas Airlangga.

Rusbariand, Septian Prima. 2012. Analisis Pengaruh Tingkat Inflasi, Harga Minyak Dunia, Harga Emas Dunia, Dan Kurs Rupiah Terhadap Pergerakan Jakarta Islamic Index Di Bursa Efek Indonesia. Prosiding Seminar Nasional. ISBN : 978-602-17225-0-3. Universitas Gunadharma.

Siregar, Syofian. 2014. Statistika Parametrik Untuk Penelitian Kuantitatif. Jakarta: PT. Bumi Aksara.

Suciningtias, Siti Aisiyah. 2015. Analisis Dampak Variabel Makro Ekonomi Terhadap Indeks Saham Syariah Indonesia (ISSI). Jurnal 2nd CBAM, ISSN 2302-9791, Vol. 2, No. 1. Universitas Islam Sultan Agung.

Suharyadi Dan Purwanto S. K. 2016. Statistika Untuk Ekonomi Dan Keuangan Modern. Jakarta: Salemba Empat.

Sukirno, $\quad$ Sadono. 2013. Makroekonomi Teori Pengantar. Jakarta: PT. Raja Grafindo Persada. 
Sukmana, Yoga. 2016. Mulai 19 Agustus, BI Tinggalkan BI Rate, Penggantinya "7-Day Repo Rate". Error! Hyperlink reference not valid.. Diakses Pada Tanggal 11 Juli 2017.

Surbakti, Edhy Priyatna Anugrah, 2011. Pengaruh Non Farm Payroll, Suku Bunga Bank Sentral Amerika Serikat (The FED), Dan Indeks Nikkei 225 Terhadap Indeks Dari SahamSaham Perusahaan Berbasis Syariah Di Jakarta Islamic Index. Jurnal Akuntansi Volume 3 No 1 Mei 2011. Universitas Maranatha.

Syafii, Muhammad. Hafindhoh dan Hilman Fauzi. 2013." The Islamic Capital Market Volatility A Comparative Study Between In Indonesia And Malaysia. Jurnal Liquidity Vol. 2, No. 1 hlm 112.

Vejzagic, Mirza dan Hashem Zarafat. 2013. Relationship Between Macroeconomic Variables and Stock Market Index: CoIntegration Evidence From
FTSE Bursa Malaysia Hijrah Shariah Index. Asian Journal of Management Science and Education, Vol.2 No.4 hal.94108,October 2013 ISSN:2186845X. Limkokwing University Of Creative Technology Malaysia.

Wicaksono, Immanuel Satrio. 2017. Pengaruh Fed Rate, Indeks Dow Jones, Nikkei 225,Hang Seng Terhadap Indeks Harga Saham Gabungan. E-Jurnal Akuntansi Universitas Udayana Vol.18.1. Januari 2017. ISSN: 2302-8556.

Wijayaningsih, Ria, 2016. Pengaruh Bi Rate, Fed Rate, Dan Kurs Rupiah Terhadap Indeks Harga Saham Gabungan (IHSG) Periode 2008-2015. Jurnal Administrasi Bisnis (Jab) Volume 33 No. 2 April 2016. Universitas Brawijaya.

Wiyono, Gendro.2011. Merancang Penelitian Bisnis Dengan Alat Analisis

SPSS 17.0 \& SmartPLS 2.0. Yogyakarta: STIM YKPN Yogyakarta. 